\title{
Transmitting Cultural Identity in Schools through Traditional Music: A Case Study of Three Districts in Zimbabwe
}

\author{
Shadreck Mataruse \\ Department of Teacher Development \\ Great Zimbabwe University \\ P.O Box 1235, Masvingo, Zimbabwe \\ Tel: 263-773-178-292Ｅ-mail: shadmataruse@yahoo.com
}

Received: January 23, 2017

Accepted: March 8, 2017

Published: April 15, 2017

doi:10.5296/gjes.v3i1.10638

URL: https://doi.org/10.5296/gjes.v3i1.10638

\begin{abstract}
Traditional music may be used to transmit and preserve cultures of various societies in schools. To address the above concern, the researcher carried out a study on traditional music performances in three Zimbabwean districts. The study employed a qualitative approach. Audio visual recordings, interviews and questionnaires were used for data collection. The population comprised members from three districts and music teachers from the selected schools. The study revealed that music education may be of meaningful value to societies when local traditional songs are used. The study also disclosed that traditional music plays a pivotal role in instilling the expected norms, values and standards in children. Respondents advocated that traditional songs should be taught to young generations because, through these, the young can learn the behaviour they are expected of, to become functional members of the society. The research recommends that local traditional songs should be used in teaching music. What is taught in schools should be culturally relevant to and affirming of the students' lived realities. The school authorities should encourage the inclusion of local traditional songs in music instruction. Teachers and parents should also work together to transmit culture through generations using oral and literal means.
\end{abstract}

Keywords: Traditional music, Cultural identity, Transmission, Cultural framework, Ethnomusicology 


\section{Introduction}

This study has been greatly influenced by Lawton's view that curriculum is a selection from culture (Lawton, 1975). The issue of the role of music education in schools has been of concern for a long time. While it is the aim of every school curriculum to mould functional and socially accepted members of the society, music teachers, especially those in Africa still have some challenges on how they can use African traditional songs to celebrate their cultural identity. Although the curriculum encourages the use of local music in teaching musical concepts, most syllabi provided do not refer to sources where the local songs may be found (Mugochi, 1988). It remains the duty of the music educator to identify songs that may be useful in teaching music education. The sources of content available are mostly Western. Africa has her own traditional compositions that may be used by music educators to teach music in schools. Unfortunately, very little is documented on African traditional compositions. Indigenous African music has relied entirely on an oral tradition of transmitting musical knowledge (Nompula, 2011).

Like in any other culture, African children come to school with a variety of personal experience to the classroom. If teachers carefully utilise this experience, a culturally appropriate pedagogy designed to motivate and empower students is brought about (Hale, 2001). Understanding how students' musical experiences are mediated by culture is critical for educators interested in student learning (Lind \& Mckoy, 2007). It has also been argued by Hale (2001) that community settings must relate to educational opportunities. Teachers must, therefore, be willing to acknowledge, value and work from the cultural and linguistic resources their students bring to school (Cochran, 2004)

This research aims to find out how best local traditional music may be used in coming up with a meaningful and constructive instruction in music education. It is the researcher's strong belief that teaching traditional music in schools may assist in shaping the behaviour of children in various societies so that they become functional and acceptable members of their societies. Through music, societies celebrate their cultural identity as different from other societies. Music plays an integral part in the influence of identity upon members of society (Craig, 2015).

Various ethnomusicologists like Blacking (2000), Waterman (1995), Berliner (1993) and Chernoff (1997) have studied the music of Africa, investigating the meaning of music to humankind and its effects on a given culture. African music is a cultural activity which reveals a group of people organising and involving themselves with their own communal relationships. The aesthetic point of the exercise is not to reflect a reality which stands behind it but to ritualise a reality that is within it (Frith, 1996). Music has an impact on society for as long as people have made the music and listened to it. Blacking (2000) has defined music as humanly organised sound whose patterns are appreciated by the community. Music, therefore, becomes a product of social construction and is inherited from one generation to another through either oral or literal means (Hall \& Du Gay, 1996).

Music education should, therefore, be influenced by the music that is performed by local members of the societies in which it is being taught. This suggestion is derived from the view 
that musicians behave in a certain way that makes them different from the rest of the community, yet what they do should be a product of the aspirations of the same community they live in (Blacking, 2000). It is against this background that the researcher decided to carry out a study on how music can be used to transmit cultural identity to children in schools. This research was carried out in three Zimbabwean districts namely Gutu, Bikita and Chipinge.

\subsection{Research question}

- How can local traditional music be used in transmitting cultural identity in schools?

\subsubsection{Sub research questions}

- What is the view of the local societies towards the teaching of music in schools?

- Is there any meaningful content that may be derived from local traditional songs for music education instruction?

\section{Methodology: Design, Procedure and Participants}

In examining how music may be used in exhibiting and celebrating cultural identity in schools, the researcher mainly employed the qualitative research design. This design was chosen for its requirement for the researcher to be a participant observer and its ability to describe the real state of affairs. Chua, High, and Lau (2008) note the importance of this design by highlighting its major purpose in describing the state of affairs as they exist. Yates, Starnes, and Moore (2008) also indicate that a qualitative research design helps in capturing the complexity of everyday behaviour. Furthermore, Nketia (2005) postulates that qualitative research is field oriented. The researcher should be part of the respondents. This would help the researcher to provide a rich description of cultural scenes, practices and beliefs.

In this study, the researcher visited the research areas to record musical performances and carried out interviews that were used as data for this study. Prior arrangements were made with the respondents so that the researcher would know of the various gatherings where music was to be performed. Each district was visited twice during the period of study. The first visit aimed at making arrangements with selected respondents to find out when they would carry out their performances. The second visit was for collecting data.

Data for this study were collected from three Zimbabwean districts. Purposive sampling was used to get the three districts whose residents became the population of the study. The sampling procedure was purposive so as to reduce travelling costs since the chosen districts are neighbouring and not far from Masvingo urban where the researcher resides. The researcher selected the respondents for this study in such a manner that both sexes and various age groups were represented. Six respondents were chosen from each district using stratified sampling. Two respondents, a male and a female, were selected from each of the following age groups, fifteen to thirty-nine years, forty to sixty-four years and sixty five years and above thus making a total of eighteen respondents from the selected districts. Six music teachers were also purposively sampled from the six selected schools in the three districts.

The main instrument used in this study was the interview. The respondents in the interviews 
were selected members of the local communities as well as music teachers from the selected schools. The main aim of the interviews conducted was to find out the views of the respondents on how local traditional music may be used in transmitting cultural identity in schools. The interviews also sought to find out if there is teaching content that may be derived from traditional songs to use in music instruction. Music teachers were also provided with a questionnaire in search of the above information so as to get the validity of given responses.

The researcher used audio visual recordings and a journal to record information for later analysis. At least two traditional songs were recorded from each district and the lyrics were later used to explain how music can be used in transmitting cultural identity in schools. The researcher also used selected respondents aged sixty five years and above to interpret the recorded song lyrics.

Data collected in this study was analyzed using qualitative methods. The researcher used the descriptive narrative technique to analyze data from conducted interviews, questionnaire as well as audio visual recordings of what transpired during performances. The researcher observed six separate performances during this study. These were analysed separately, aiming at finding out how younger generations in schools may benefit from different traditional musical performances in their society.

\section{Findings}

\subsection{Findings from Interviews}

The main aim of the interview was to establish the views of the respondents on how local traditional music may be used in transmitting cultural identity in schools. The interview also sought to find out the views of the local society towards the teaching of music in schools as well as establishing whether music educators in schools use local traditional songs in music lessons and their ability to derive teaching content from local traditional songs.

Most respondents outside the school concurred that there should be a relationship between music education in schools and music that is practiced at home. They viewed the school as the supporting arm of the society that should assist in moulding the young into the acceptable and functional members of the society. Some of the respondents even went further to establish how dangerous it may be if what is taught in schools opposes the culture of the local community. A few respondents, however, viewed music education in schools as "too smart" to focus on local traditional songs. These suggested that music education in schools should focus on teaching the Western "art" music. These emphasized on teaching of Western instruments as well as choral music in schools. "There is no reason of teaching the young what they already know from home; teach them new things they do not know", one of the respondents explained.

All the interviewed music teachers agreed that, if well taught, music education can play a pivotal role in instilling the society's expected qualities in children. All the teachers agreed that there is a lot of teaching content that can be derived from local African traditional songs for music instruction in schools. They however, indicated on the challenging skills that may 


\title{
Macrothink
}

Global Journal of Educational Studies

ISSN 2377-3936

2017, Vol. 3, No. 1

be required in coming up with such content. Due to this, most music teachers would resort to readily available content in teachers' resource books neglecting music from the local society.

\subsection{Findings from Questionnaire}

The questionnaire was only given to the selected music educators. This was done as a follow up measure to find out the correlation of responses given in interviews as well as those given in questionnaires. All the six issued questionnaires were responded to and later collected by the researcher.

Like what was indicated in the interviews, the responses in the returned questionnaire showed the importance of local songs in teaching music in schools. The responses indicated the strong relationship between education and culture. Through using local traditional songs in schools, the teacher would be in a way preparing the young into acceptable members of the society.

\subsection{Findings from Recorded Song Lyrics}

At least two songs were recorded from each of the selected districts. Selected respondents aged sixty five and above were interviewed to give meanings of the recorded lyrics. Below are the two song lyrics recorded in Gutu District:

\subsubsection{Song 1. Kusarima}

\author{
Kusarima hooyee kusarima hooyee \\ Kusarima hooyee torai mapadza muchirima \\ Gore randakabata chihwerekwere, \\ Vadzimai vaenda kumunda \\ Sadza rakamanya semudhudhudhu \\ Torai mapadza muchirima \\ Kuzoti ndaribika nemujakari \\ Rakamira serine zvipikiri \\ Zvinobvirawo here vakomana \\ Torai mapadza muchirima
}

When literally translated to English the song lyrics read:

Not engaging in farming activities is bad therefore take the hoes and work in the fields. The day I trapped the wild bird whilst my wife was working in the fields, I enjoyed my meal. But the day I prepared sadza with wild vegetables as relish, it was as if I was eating iron nails and that was really bad. 


\title{
Macrothink \\ Global Journal of Educational Studies \\ ISSN 2377-3936 2017, Vol. 3, No. 1
}

3.3.2 Song 2. Gara Mukuwasha

\author{
Mbuya ndoenda \\ Gara mukuwasha iwe gara \\ Mbuya ndoenda \\ Gara mukuwasha iwe gara \\ Sadza wadya here? \\ Gara mukuwasha iwe gara \\ Kugara kunzwanana \\ Gara mukuwasha iwe gara
}

English translation:

Mother in law I am leaving. Please son in law stay a while please. Have you eaten your sadza? Please son in law stay a while please. There is need for mutual understanding for one to stay. Please son in law stay a while please.

Following are the two songs recorded in Bikita District:

\subsubsection{Song 1. Nyuchi Dzinoruma}

Tora uta hwako ndoda kuenda dzino-ruma

Hooye woye woye dzino-ruma

Nyuchi dzino-ruma dzino-ruma

Tora uta hwako ndoda kuenda dzino-ruma

Hooye woye woye dzino-ruma

Nyuchi dzinorumaa dzinorumaa

Tora uta hwako ndoda kuenda dzinoruma

Take your bow and arrow I am ready to go. The bees sting dangerously so take your bow and arrow for I am ready to go.

3.3.4 Song 2. Waiona Hore

Iye woye woye waiona hore

Ndiwe iwe waiona hore iyo

Taniwa nemvura tanga tichiida

Waiona hore taniwa nemvura

Torima minda yedu taniwa nemvura

Iyewo waiona hore taniwa nemvura 


\title{
Macrothink
}

Global Journal of Educational Studies

ISSN 2377-3936

2017, Vol. 3, No. 1

You have seen the cloud. The rains are coming for there is the cloud. The rains are coming. We have been waiting for it. Now we can cultivate our fields. You have seen the cloud, the rains are coming.

From Bikita District, the researcher visited Chipinge District where the following songs were recorded.

\subsubsection{Song 1. Woyee Iye Woye Haye}

Woyee iye woye haye woyee iye woye haye

Woyee iye woye haye woyee iye woye haye

Varumewee tipei doro timbonwa woyee iye woye haye

Madzimaiwee tipei doro timbonwa woyee iye woye haye

Tikabatana tinokunda muvengi woyee iye woye haye

Teshe tozofara nekurara hope woyee iye woye haye

Gentleman may you please give us some beer to drink. Ladies may you please give us some beer to drink. United we defeat the enemy and together we shall be happy and have peaceful nights.

\subsubsection{Song 2. Tinonaya Here}

\author{
Here tinonaya, here tandonayi \\ Mukadzi wangu wanyora tsamba \\ Ndanzwa ndiri Joni mwana ndokurwara \\ Anonzwa zvinyoka ndaida kuchona \\ Ndiko saka ndakauya here tinonaya \\ Gege ji ge ji ji here tinonaya
}

Are we going to recover? My wife wrote a letter while I was in Johannesburg. She was notifying me that the baby is not well. He was suffering from diarrhoea. I wanted to stay in Johannesburg forever but for this reason I am back home.

\section{Discussion}

After analysing findings from song lyrics, interviews and the questionnaire, this study revealed that the use of local traditional songs in music education may help to encourage young people's awareness of having values and their corresponding relationship to the world in which they live. Hard work and sharing are highly valued in African cultures. The lyrics torai mapadza muchirima, 'take hoes and cultivate the fields', as well as sadza wadya here, 'have you eaten sadza' encourage the spirit of hard work and sharing within the members of the society. The use of local traditional songs in Music education can therefore be used to transmit cultural identity in schools and thereby moulding the desirable characters of the society. Through the use of local traditional songs, music education can bring about a 
democratic society with individuals who have many skills among them the skill to deal with conflict management in a peaceful manner. The lyrics, kugara kunzwanana, gara mukuwasha iwe, sadza wadya here. 'I can only stay where there is peace; no, stay a while and have a meal' build in children the values of peaceful conflict management and resolution and, as according to the lyrics, this is done over a meal.

The use of local traditional songs in music education can also give as many children as possible the best general education which will enable them to deal with a complex society and to form their own definite opinions about political, economic, legal and scientific facts. Taking courage on facing frightening and dangerous situations for better results is encouraged, nyuchi dzinoruma, tora uta hwako ndoda kuenda 'although the bees sting, take your bow and arrow and face them'. The songs also teach the young about the importance of unity in defeating the enemy hence the lyrics tikabatana tinokunda muvengi, teshe tozofara nekurara hope 'united we conquer the enemy and together we shall be happy and have peaceful nights'.

Responsibility and division of labour as core values of every culture can also be transmitted to the younger generations through the use of local traditional songs in music education. The husband is in the forest hunting while the wife is working in the fields for self sustenance, gore randakabata chihwerekwere vadzimai vaenda kumunda 'the day I trapped the wild bird whilst my wife was working in the fields'. The Ndau song lyrics, mukadzi wangu wanyora tsamba, ndanzwa ndiri Joni, mwana ndokurwara, anonzwa zvinyoka, ndiko saka ndauya. 'my wife wrote a letter while I was in Johannesburg notifying me of the child suffering from diarrhoea and for this reason I am back home' also teach the roles of males and females in the society. The women look after the children at home while men search for employment in local towns and in diaspora in order to provide for their families.

Research findings from this study go along with the view by Matiure (2000) that culture can be transmitted from one generation to another through music that is taught, either orally or literally. It therefore becomes the duty of African music teachers to derive meaningful content from local traditional songs for music education instruction since indigenous African music has relied entirely on an oral tradition of transmitting musical knowledge (Nompula, 2011).

\section{Conclusion}

The purpose of this study was to find out if local traditional songs can be used to transmit cultural identity in schools within various societies. In an attempt to address the above concern the study examined traditional musical performances in three Zimbabwean districts namely Gutu, Bikita and Chipinge. Local members of these districts as well as music teachers from selected schools became participants of this study. Data was collected and analysed using the descriptive narrative technique. Research findings revealed that a meaningful and productive music education programme can be born in schools through the use of local traditional songs. Through local traditional music, young members of the society are taught how to become positively functional within the societies they live.

The research unveiled that Africa has her own traditional songs that may be used in teaching 
music in schools. Teachers should therefore be discouraged to rely on sources of content that are mostly Western. The study revealed that the use of local traditional songs in music education has a positive impact in transmitting cultural identity to children in schools. Through traditional songs, the young generations become aware of having values and their corresponding relationship to the world in which they live. This research also uncovered that most music educators face challenges when trying to come up with relevant teaching content from locally performed traditional songs.

Although this research contributed to the improvement of music teaching in schools, it had its own limitations also. The researcher only visited three out of sixty-three Zimbabwean districts. The visited districts may not fully represent what is happening in the remaining districts. The researcher also faced challenges since some of the respondents were reserved in providing information as according to their cultures. However, despite the mentioned limitations, the researcher intents to carry out another study on how music educators may be equipped with skills to sift teaching content from locally performed traditional songs.

\section{Recommendations}

Basing on the findings of this research, the study recommends that local traditional songs should be used in teaching music. What is taught in schools should be culturally relevant to and affirming of the students' lived realities. This would go along with Durkeim's theory, in Lawton (2012) which emphasises that education should meet social needs which are consensually accepted in the society.

The study also recommends that school authorities should encourage the inclusion of local traditional songs in music instruction. This would help preserving cultural identity in schools as viewed by Shizha (2013) on the suggestion that, 'schools should become cultural spaces and centres that provide strategies to reclaim African cultural identity to counteract threats of cultural identity loss'. Teachers and parents should also work together to transmit culture through generations using oral and literal means.

\section{References}

Berliner, P. (1993). The Soul of Mbira: Music and Traditions of the Shona People of Zimbabwe. Chicago and London: The University of Chicago Press.

Blacking, J. (2000). How Musical Is Man? Seatle and London: University of Washington Press.

Campbell, A. (2000). Cultural Identity as a Social Construct. Intercultural Education, 11(1), 31-39. http://dx.doi.org/10.1080/146759800500005370

Chernoff, J. M. (1981). African Rhythm and African Sensibility: Aesthetics and Social Action in African Musical Idioms. Chicago: University of Chicago Press.

Chua, L., High, C., \& Lau, T. (Eds.) (2008). How Do we know? Evidence, Ethnography and the Making of Anthropological Knowledge. New Castle: Cambridge Scholars Publishing.

Cochran, S. M. (2004). Walking the road: Race diversity and social justice in teacher 
education. New York: Teachers College Press.

Craig, A. (2015). The Influence of Music on Cultural Identity. Retrieved from https:www.linkedin.com/pulse/influence-music-cultural-identitycraig-austin

Frith, S. (1996). Music and Identity in Questions of Cultural Identity. http://dx.doi.org/10.4135/9781446221907.n7

Hale, J. E. (2001). Learning while Black. Creating educational excellence for African American children. Baltimore, MD: The Johns Hopkins University Press.

Hall, S., \& Du Gay, P. (1996). Questions of Cultural Identity. London: Sage.

Lawton, D. (2012). Class, Culture and the Curriculum. London and Boston. Routledge and Kegan Paul.

Lind, V. L., \&Mckoy, C. L. (2007). Enquiry and access in music education: conceptualising cultures as barriers to and support for music learning. Music Education Research, 9(2). http://dx.doi.org/10.1080/146138800701384375

Nketia, J. H. K. (2005). Ethnomusicology and African Music: Mode of Inquiry and Interpretation. Afram Publications.

Nompula, Y. (2011). Valorising the Voice of the Marginalised: Exploring the Value of African Music in Education. South African Journal of Education, 31(3), 369-380. https://doi.org/10.15700/saje.v31n3a542

Shizha, E. (2013). Counter Visioning Contemporary African Education: Indigenous Science as a Tool for African Development. In E. Shizha, \& A. A. Abdi (Eds.), Indigenous Discourses on Knowledge and Development in Africa.

Thorsen, S. M. (2002). Addressing Cultural Identity in Music Education. Talking Drum, 84, 1-7. $\quad$ Retrieved from http://www.hsm.gu.se/digitalAssets/848/848794-Talking-Drum-220102-pdf

Tuckman, B. (1965). Development Sequence in Small Groups. Psychological Bulletin, 63(6), 384-399. http://dx.doi.org/10.1037/h0022100

Waterman, A. C. (1990). Juju: A Social History and Ethnography of an African Popular Music. Chicago and London: University of Chicago Press.

Yates, D., Starnes, S., \& Moore, D. (2010). The Practice of Statistics. U.S.A: W.H Freeman.

\section{Copyright Disclaimer}

Copyright for this article is retained by the author(s), with first publication rights granted to the journal.

This is an open-access article distributed under the terms and conditions of the Creative Commons Attribution license (http://creativecommons.org/licenses/by/3.0/). 